\title{
LUKIJALLE
}

\section{Kansallinen omakuva ja kielteiset tunteet}

Kaunokirjallisuudella on ollut keskeinen rooli kansallisen yhteenkuuluvuuden tunteen ja isänmaanrakkauden virittäjänä eri maissa. Myös suomalaiskansallista tunneyhteisöä on rakennettu kirjallisuuden inspiroiman isänmaanrakkauden voimin. 1800-luvun kansallisromantiikassa, kuten J. L. Runebergin ja Z. Topeliuksen teoksissa, kuvattiin ja herätettiin yhteisöä rakentavia kiintymystunteita, kuten rakkautta, liikuttuneisuutta sekä niihin yhdistyviä, uskonnollista kokemusta muistuttavia kuulumisen ja yhteyden tunteita. Traaginen kärsimys estetisoitiin ja esitettiin moraalisesti ylevöitettynä: köyhyyden ja sodan aiheuttamalle tuskalle ja kivulle haettiin oikeutusta isänmaan hyväksi annetusta epäitsekkäästä uhrista. Esimerkiksi Topeliuksen Boken om Vårt Land -teokseen (I875, suom. Maamme kirja) sisältyvässä runossa "Ditt land” (suom. "Maasi”) runon puhuja osoittaa sanansa "Suomen lapselle", joka kasvatetaan pienestä pitäen puolustamaan isänmaataan ja uhrautumaan sen puolesta:'

\footnotetext{
Vem är så rik som du, och vem har fått ett härligare hem att älska och försvara? Guds kärlek gav dig allt, och allt är åt din kärlek anbefallt.

O, Finlands barn, väx i dess vård, som vårens björk i blomstergård; var trofast intill döden, och vig ditt hjärta, räck din hand åt ditt och dina fäders land!
}

Z. Topelius: "Ditt land"2

Runossa rakkaus isänmaahan ja Jumalaan samaistetaan, ja tätä protestanttista liittoa lujittaa ajatus isänmaan vuoksi tehdyn työn pyhyy-

\footnotetext{
' Topeliuksen runossa kuvattu uhrautuminen ja kaunis maisema ovat tyypillisiä liikuttumisen tunteen ärsykkeitä. Liikuttuminen on tärkeä yhteisöä rakentava kiintymystunne, jolla on evoluution näkökulmastakin ollut tärkeä tehtävä yhteisön säilymisessä. Liikuttuessaan yksilö kokee tyypillisesti yhteydentunteita toisiin ja voi kokea moraalisen hyvän läsnäolon. (Ks. Cova ja Deonna 20I4; Menninghaus et al. 20I5; Deonna 20I8.) Kansallistunteisiin tavallisesti liittyy positiivisia itsen menettämisen kokemuksia, jotka syntyvät toimimisesta jonkin itseä suuremman hyväksi. Tämän vuoksi niiden on katsottu myös muistuttavan uskonnollisia tunteita. (Hogan 2009: 75.)

2 Topelius 1937: II. Pidempi versio "Ditt land" -runosta ilmestyi ensimmäisen kerran Boken om Vårt Land -teoksen vuoden 1886 painoksessa.
} 
destä. Jumalalta lahjaksi saadun ihanan maan äärellä viriävät liikuttumisen ja ihmetyksen tunteet, toivo ja varmuus Suomen kansan valoisasta tulevaisuudesta.

Samalla kun patrioottinen kirjallisuus on pyrkinyt herättämään epäitsekästä isänmaanrakkautta, kansallisylpeyttä ja tulevaisuuden toivoa, monet kirjallisuutemme kuvaukset suomalaisesta kansanluonteesta ja leimallisesti suomalaiskansallisista tunteista kertovat toista tarinaa. Esille nousevat kielteiset tunteet ja niiden intensiivinen ilmaisu. Tälle kuvaukselle pohjan loi Topelius itse: Boken om Vårt Land -teoksen stereotyyppinen suomalainen, Matti, on työteliäs, rehellinen ja rakastaa kotiaan, mutta häntä luonnehtivat myös itsepintaisuus, juro sulkeutuneisuus ja äkillisesti leimahtava kiukun tunne, jolla ei syttyessään ole mitään rajoja. ${ }^{3}$ Suomalaisten omaperäisenä kansallistunteena pidetty sisu saa monia muotoja Aleksis Kiven Seitsemässä veljeksessä (I870), jossa pauhaa primitiivinen vihan vimma. ${ }^{4}$ Kiukun ja suuttumuksen muunnelmia kohdataan myös Joel Lehtosen Putkinotkossa (1919-20), jossa suomalaiset on kuvattu herkästi tuntevana alkukantaisena villikansana. ${ }^{5}$ Naturalismin perinteessä kielteisillä tunteilla on usein ollut kriittinen ja lukijaa aktivoiva tehtävä: Minna Canthista ${ }^{6}$ Lehtoseen inhimillisen kärsimyksen shokeeraavat esitykset pakottavat lukijan kohtaamaan kuvatut yhteiskunnalliset ongelmat ja virittävät moraalista suuttumusta yhteiskunnan epäkohdista.

Sisun ohella suomalaisen kansanluonteen perustunteena on pidetty melankoliaa, josta on tullut kulttuurinen klisee. Kantelettaresta Eppu Normaaliin ja Aki Kaurismäen elokuviin kulttuurinen mentaliteettimme on määritelty "suruista tehtynä soittona"" ja Suomea on kuvattu raskasmielisenä ja väkivaltaisena "murheellisten laulujen maana", jossa Eino Leinon "Lapin kesä" -runon (I902) sanoin "kaikki kaunis tahtoo kuolla, ja suuri surkastua alhaiseen". ${ }^{8}$ Monissa suomalaisen kansanluonteen esityksissä nähdään vimman ja melankolian synteesi. Esimerkiksi Marko Tapion 1960-luvulla julkaistuissa Arktinen hysteria -sarjan romaaneissa Vuoden 1939 ensilumi (1967) ja Sano todella rakastatko minua (1968) kirjailija esittää maanis-depressiivisenäkin nähdyn "arktisen hysterian" kaikkia yhteiskuntaluokkia läpäisevänä kansantautina. Se kumpuaa pohjoisen luonnon ääriolosuhteiden vaikutuksesta mieleen ja kehoon sekä alakulon leimaamasta kansanluonteesta, mutta myös vanhojen ihanteiden katoamisesta, luonnon hyötykäytöstä ja sille aiheutetusta tuhosta.

Käsillä oleva Joutsenen erikoisjulkaisu Suomalaiset ahdistukset Kansallinen omakuva ja kielteiset tunteet lähestyy kansakunnan kertomisen kysymyksiä kielteisten tunteiden näkökulmasta. Julkaisussa pohditaan erityisesti kielteisten tunteiden ja niin sanottujen rumien, kulttuurisesti

\footnotetext{
3 "Till Mattis senfärdighet hör, att han tål mycket, innan han vredgas, men en gång vred, blir han ofta vred öfver all måtta" (Topelius 20 I7: I44).

${ }^{4}$ Veljesten vimmasta ja tunteellisuudesta ks. Lyytikäinen 2004.

${ }^{5}$ Tunteista ja niiden tehtävästä Putkinotkossa, ks. Rossi 2020.

${ }^{6}$ Passioista kärsimyksenä ja intohimona Canthin teoksissa ks. Maijala 2008.

${ }^{7}$ Viittaamme tässä Kantelettaren (1997: 3) I. kirjan I. runoon "Eriskummainen kantele": "Soitto on suruista tehty / murehista muovaeltu: / koppa päivistä kovista, / emäpuu ikipoloista, / kielet kiusoista kerätty, / naulat muista vastuksista".

${ }^{8}$ Leino 1902: 78.
} 
ja moraalisesti vähäarvoisina pidettyjen tunteiden merkitystä suomalaisen omakuvan rakentumiselle. Miten pelkoa, inhoa, vihaa, kateutta, surua, ahdistusta tai syyllisyyttä on kuvattu suomalaisessa kirjallisuudessa? Miten nämä esitykset suhteutuvat myönteisinä ja moraalisesti korkeina pidettyihin kansallistunteisiin kuten isänmaanrakkauteen tai yhteenkuuluvuuden tunteeseen? Millaisiin kirjallisuushistoriallisiin ilmiöihin ja esteettisiin käsityksiin negatiivisten tunteiden esittäminen kytkeytyy? Entä millaisia tunnereaktioita, joko myönteisiä tai kielteisiä, näiden tunteiden kuvauksilla pyritään lukijassa herättämään ja millaisin keinoin? Kansakunnan rakentamisen kysymyksiä tarkastellaan lisäksi suhteessa 2000-luvun poliittisessa keskustelussa hyödynnettyyn affektiiviseen retoriikkaan, joka ammentaa kielteisistä kollektiivisista tunteista. Millaisia ovat nykypäivän kertomukset suomalaisuudesta ja millä tavoin ne lujittavat tai haastavat I800-luvulta lähtien yhdessä kuviteltua kansakuntaa? Entä millaisia uusia tunneyhteisöjä nämä kertomukset rakentavat?

Näitä kysymyksiä pohtimalla erikoisjulkaisu tarjoaa uusia näkökulmia kuvitellun kansakunnan tutkimukseen. Kaunokirjallisuus on ollut Suomessa keskeinen osa kansakunnan kuvittelemisen projektia, josta Benedict Anderson klassikkoteoksessaan Imagined Communities (1983) kirjoitti. Kansallisen kuvittelussa ei ole kyse pelkästään fiktiivisten tarinamaailmojen yhteisöistä vaan myös todellisten yhteisöjen rakentumisesta. Kaunokirjalliset yhteisö- ja yksilökertomukset ovat vaikuttaneet syvällisesti kulttuurisiin käsityksiin suomalaisuudesta ja muokanneet suomalaista omakuvaa. Aiheesta on aikaisemmassa tutkimuksessa kirjoitettu suhteellisen runsaasti (esim.Viikari 1996; Lyytikäinen 1999; Kirstinä 2007; Grönstrand et. al 2016). Kansakunnan kertomisen affektiivista ulottuvuutta on kuitenkin tarkasteltu vähemmän, vaikka kysymys tunteista on monella tavalla nationalismin ytimessä. Jo I800-luvun nationalismin teoreetikot totesivat, että kansallisuusaatetta kannattelevat nimenomaan tunteet. Isänmaallisuus tai patriotismi määriteltiin tunnetason sitoutumiseksi tiettyyn kansallisidentiteettiin. Ernst Renan (I882: 27) piti jaetun kokemuksen, solidaarisuuden tunteen ja yhteisen uhrimielen syntymistä kansallisuusaatteen ehtona. 1800-luvun nationalismin globaalia leviämistä on selitetty kansallisuusaatteen kyvyllä herättää erilaisia yhteenkuuluvuuden tunteen variantteja, jotka korvasivat uskonnollisia tunteita maallistuvassa modernissa maailmassa (esim. Hobsbawm 1994: 56).

Kansakunta käsitetään usein syväksi, kaiken läpileikkaavaksi toveruudeksi huolimatta epätasa-arvoisuudesta ja riistosta, joka sen sisällä väistämättä vallitsee (Anderson 1983: 4I). Yhteenkuuluvuuden kokemus, joka toimii kansakunnan koheesiota tuottavana voimana, vaatii kuitenkin jatkuvaa työtä. Kaunokirjallisuudella on ollut keskeinen rooli kansallisidentiteetille ominaisen tunnesiteen luomisessa ja kansallistunteiden kulttuurisessa koodaamisessa, niin sanotussa affektiivisessa mallintamisessa. ${ }^{9}$ Kirjallisuus ja taide ovat olleet keskeinen osa "kansallistamisen

\footnotetext{
${ }^{9}$ Esimerkiksi Margaret Wetherell (2012: I3-16) on kirjoittanut diskursseissa ja vuorovaikutuksessa tapahtuvasta affektiivisesta mallintumisesta ja tunteiden ritualisoitumisesta. Yhteisöjen affektiiviset käytännöt muovaavat yksilöllisiä tunteita, ja tästä
} 
tekniikoita", joilla kansallisidentiteettiä etualaistetaan suhteessa muihin identiteettikategorioihin (esim. Hogan 2009). ${ }^{10}$ Suomessa rakkautta kotimaahan ja omaan kansaan on juurrutettu varsinkin kouluopetuksessa, jossa kaunokirjallisuus, kuten J. L. Runebergin runot ja Z. Topeliuksen Maamme kirja olivat 1900-luvulla vuosikymmeniä kansakoulujen oppimateriaalina virittämässä kansallistunteita nousevaan nuorisoon.

\section{Kirjallisuus ja kielteiset tunteet}

Joutsen / Svanen-erikoisjulkaisu Suomalaiset ahdistukset koostuu seitsemästä artikkelista, jotka tarkastelevat kansakunnan kuvittelun affektiivista poetiikkaa keskittymällä erityisesti kielteisinä pidettyihin tunteisiin. Artikkeleissa lähestytään "suomalaisia ahdistuksia" eri tyylisuuntien ja tekstilajien valossa sekä tutkitaan kerronnallisia, retorisia ja tyylillisiä keinoja, joilla kirjallisuuden tunnevaikutuksia luodaan. " Analyysin kohteena ovat henkilöhahmojen ja kertojien tunteiden ohella tekstin tunnelmaan eli emotionaaliseen sävyyn kiinnittyvät tunteet ja tuntemukset, oletetulle lukijalle suunnatut tunne-efektit sekä teosten tyylin, lajin ja intertekstuaalisuuden mukanaan tuomat genrespesifit tunteet ja käsitykset tunteista. Artikkeleissa tutkitaan myös, kuinka tekstien tunnevaikutukset niveltyvät historiallisiin tunnerakenteisiin ja tunnehallintoihin - tai hankaavat ja hajottavat niitä - ja kuinka kaunokirjallisuus ja muut tekstilajit paitsi ilmaisevat, myös tuottavat käsityksiä tunteista.

Erikoisjulkaisun keskiössä oleva kielteisten tunteiden ${ }^{12}$ tematiikka on monitieteisessä tunteiden tutkimuksessa saanut viime vuosina uutta näkyvyyttä. Tunteiden filosofiassa ja psykologiassa negatiivisista tunteista, kuten häpeästä, inhosta, pelosta, vihasta ja surusta on ilmestynyt runsaasti uutta tutkimusta (esim. Ahmed 2004; Nussbaum 2004 ja 2018; Deonna et al. 20I I; Goldie 20I I; Ratcliffe 20I5; Tappolet et al. 2018). Hyveinä pidettyjen tunteiden ja emotionaalisten mekanismien,

näkökulmasta tunteet voidaan ymmärtää eräänlaisina yliopittuina kognitiivisina tapoina (Reddy 200I: 55).

10 Kansallistunteita virittävän taiteen ohella kansallistamisen tekniikoihin lukeutuvat muun muassa erilaiset rituaalit, kuten itsenäisyyspäivän vietto tai joissakin maissa kansalaisuuden myöntämiseen liittyvät juhlalliset valat ja seremoniat (ks. Byrne 2017). Vakiintuneimpia kansallistamisen tekniikoita on liputtaminen kansallisina juhlapäivinä. Liputuksen rituaalista symboliikkaa on vahvistettu myös Suomen lippua ylistävissä lippurunoissa (Tepora 20I I).

1 I Tunnevaikutuksen käsitteestä ks. Lyytikäinen 2016.

12 Kysymys "kielteisten tunteiden" määrittelystä on oma filosofinen ongelmansa, joka riippuu määrittelyn kriteeristä (ks. esim. Solomon ja Stone 2002). Tunteen positiivisuutta tai negatiivisuutta voidaan tarkastella subjektiivisen tunnekokemuksen, ns. hedonistisen aspektin eli mielihyvän tai mielipahan, hyve-etiikan, tunteiden sosiaalisten ja moraalisten seurauksien tai ns. emotionaalisen valenssin näkökulmasta. Esim. häpeän tunne on subjektiivisena kokemuksena epämiellyttävä ja aiheuttaa välttämiskäyttäytymistä, mutta yhteisön näkökulmasta häpeää on pidetty myönteisenä tunteena sikäli, että se pakottaa ennakoimaan ja tarkastelemaan kriittisesti tekojen seurauksia ja siten sillä on yhteisön ja yksilön kannalta "myönteinen", suojaava vaikutus. Emotionaalisen valenssin kannalta tunteen positiivisuutta tai negatiivisuutta voidaan tarkastella eräänlaisena tunteeseen sisäänrakennettuna piirteenä. Väärintekemisestä heräävän häpeän tunteen voidaan ajatella liittyvän tunteen negatiiviseen valenssiin: reagoimme kielteisesti tekoon, joka herättää häpeää (Teroni 2018: 10). 
kuten empatian hyödyistä on käyty kriittistä keskustelua (esim. Bloom 2016). Estetiikassa keskustelua on lisäksi herättänyt kysymys taiteen elimellisestä suhteesta kielteisiin tunteisiin. Winfried Menninghaus (2017) tutkimusryhmineen on tarttunut Aristoteleen jo Runousopissa esittämään ajatukseen kielteisten tunteiden ja taiteen suhteesta ja esittänyt, että kielteiset tunteet eivät ole ominaisia vain tragedian ja kauhun kaltaisille lajeille vaan jopa kaikelle taiteelle. Taide ei kätke ahdistaviksi koettuja tai kulttuurisesti epähienoina pidettyjä kielteisiä tunteita ja siivoa niitä kehitysoptimismin tai onnellisuuspuheen tieltä vaan pikemminkin nostaa ne jalustalle ja hakee negatiivisista tunteista taiteen koskettavuutta ja kumousvoimaa. Romaanilajissa erilaisten jännitteiden, koettelemusten, konfliktien ja inhimillisen kärsimyksen kuvaaminen on miltei oletusarvo. Negatiiviset tunteet, kuten pelko, inho, häpeä tai viha ovat tyypillisesti intensiteetiltään voimakkaita ja usein kokonaisvaltaisen ruumiillisia kokemuksia, jotka ovat omiaan lisäämään tarinan kerrottavuutta ja kerrotun muistettavuutta. ${ }^{13}$ Inhon, pelon ja surun tunteet liittyvät arkielämässäkin usein suuriin muutoksiin ja vaativat erityistä huomiota. Merkittävintä lukijan kannalta kuitenkin on, että kielteiset tunteet ovat omiaan synnyttämään liikuttumista ja mielihyvää. Ilmiö tunnetaan Aristoteleesta lähtien ns. tragedian paradoksina: taiteessa kuvattujen järkyttävien tapahtumien todistaminen johtaa katharttiseen kielteisistä tunteista vapautumiseen. ${ }^{14}$

Tästä näkökulmasta kansallista kertomusta leimaavia suomalaisia ahdistuksia selittää osin tapa, jolla taide ja kaunokirjallisuus ammentavat kielteisistä tunteista. Voidaan kuitenkin ajatella, että kielteisten tunteiden tehtävä taiteessa on sidoksissa kulttuurisesti ja historiallisesti muuttuviin poetiikkoihin ja estetiikkoihin, joita tämän kokoelman artikkelit kartoittavat. Suomalaiset ahdistukset -kokoelman valossa voikin todeta, että "perisuomalaisina" näyttäytyvät kansalliset ahdistukset kytkeytyvät nykyaikaistumiskehityksen ylirajaisiin ${ }^{15}$ tunnerakenteisiin ja niitä kielentävään modernismin poetiikkaan. Tässä näkökulmamme eroaa Menninghausin (2017) universalismista, jossa oletuksena on taiteen hedonistisen funktion pysyvyys eri aikoina ja eri taiteenlajeissa. ${ }^{16}$ Esimerkiksi tragedialle ominaisen katharsiksen tehtävä näyttää muuttuvan nykyaikaa kohti mentäessä. Sianne Ngai (2005) on kuvannut katharsikselle ominaisen tun-

\footnotetext{
${ }^{13}$ Lukijalle kertomusten kuvaamat ja herättämät kielteiset tunteet ovat merkityksellisiä tapahtumien havaitsemisen ja mieleen painumisen kannalta, sillä negatiivisilla tunteilla on kiinteä yhteys muistin ja havaitsemisen kognitiivisiin toimintoihin (Menninghaus et al. 20I7: 4-5).

14 Kielteisten tunteiden ja tuntemusten voimakkuus herkistää taiteen herättämille esteettisille tunteille, kuten liikuttumisen tai kosketetuksi tulemisen ambivalentille tunteelle, jossa hämmennys, mielihyvä ja suru sekoittuvat (ks. Cova ja Deonna 2014; Menninghaus et. al 2015).

${ }^{15}$ Viittaamme "ylirajaisella" kansallisen ajattelun ja kansallisvaltioiden rajat ylittävää näkökulmaan: esimerkiksi ylirajaisessa kirjallisuudentutkimuksessa kirjallista kulttuuria lähestytään irtautuen kansallisen kehyksestä, mutta pienten kielialueiden kirjallisuuksien erityispiirteet edelleen huomioiden (esim. Grönstrand et al. 2016).

16 Menninghausin ja hänen tutkimusryhmänsä kehittelemää esteettisten tunteiden teoriaa ohjaa ajatus siitä, että taiteilija pyrkii teoksellaan tuottamaan mielihyvää, liikuttamaan vastaanottajaa tai tarjoamaan hänelle miellyttävän esteettisen kokemuksen: "Summing up, important characteristics of negative emotions can be theoretically conceived as predestined resources for the artists' efforts to produce artworks that powerfully and pleasurably affect recipients" (Menninghaus et al. 20I7:5). Ks. myös Menninghaus et al. 20I5: I.
} 
teista puhdistumisen viivästymistä ja jopa vesittymistä modernin taiteen vastaanotossa. Kirjallisuuden hedonistinen funktio ja siihen liittyvä kielteisten tunteiden miellyttävä purkautuminen alkoi menettää merkitystään jo modernismin varhaisvaiheissa, kuten naturalismin ja dekadenssin inhon poetiikassa. Totuus löytyi kauneuden sijaan rumasta ja inhottavasta; epämiellyttävistä tunne-efekteistä ja lukijan shokeeraamisesta kielteisten tunteiden esittämisellä ja herättämisellä tuli keskeinen yhteiskuntakritiikin keino (ks. Rossi 2007).

Modernismin kokeellisessa kerronnassa lukijan haastamisesta, häiritsemisestä ja mielihyvän koettelemisesta tulee jopa tietynlainen normi. ${ }^{17}$ Henkilökuvauksessa korostuvat psykologisesti ja moraalisesti ambivalentit, moniulotteiset henkilöhahmot, jotka herättävät lukijoissa ristiriitaisia tunteita. 1900-luvun kirjallisuudelle leimalliset hylkiösankarit ajavat lukijan usein emotionaalisesti epämukavaan asemaan: helpon myötätunnon tai miellyttävän samastumisen sijaan nämä hahmot herättävät ns. "vaikea empatiaa", joka koettelee ja horjuttaa kokijansa identiteettiä ja vaatii lukijaa tunnistamaan oman moraalisen ristiriitaisuutensa. ${ }^{18}$ Vastahankainen henkilökuvaus korostuu myös 1900-luvun kotimaisessa kirjallisuudessa, jossa sivullisuuden, ahdistuksen ja "hulluuden" ristiriitaisista esityksistä tuli keskeinen osa modernismia ja sen kerronnallisia keinoja (ks. Makkonen 1992; Salin 2002 ja 2008; Nykänen 2018; Ovaska 2020).

Ristiriitaisen henkilökuvauksen ohella modernismin poetiikkaan palautuva kielteisten tunteiden merkitys peilautuu lisäksi kuvattujen ja herätettyjen tunteiden rumuuteen sekä uusiin tunneyhdistelmiin, joita nykyaikaa kritisoiva taide tuottaa ja kielentää. Ngain tarkastelemien tunteiden "rumuus" liittyy paitsi epämiellyttäviin tunnekokemuksiin, myös rumien tunteiden luonteeseen epämääräisinä, vaikeasti hahmotettavina ja pitkittyneinä, kulttuurisesti toissijaisina ja jopa epämoraalisina pidettyinä tunnetiloina. Toisin kuin surun tai häpeän kaltaisilla "arvokkaina" pidetyillä negatiivisilla tunteilla, niin sanotuilla rumilla tunteilla, kuten ahdistuksella ja inholla, ei ole potentiaalisesti moraalisesti jalostavaa vaikutusta. Modernin kehyksissä perinteisesti ylevinä pidettyjen tunteiden luonne muuttuu ja saa uusia merkityksiä. Taiteen ja kirjallisuuden kuvaamaa modernia on luonnehdittu affektiiviselta ilmapiiriltään melankoliseksi (Flatley 2008), sillä modernin kokemusta leimannut muutos on merkinnyt katkosta ja erontekoa suhteessa oletettuun esimoderniin. Ylevöittävän yksinäisyyden tai nautintoa tuottavan surun sijaan modernia melankoliaa sävyttää kuitenkin usein tunteiden ironinen etäännyttäminen, tunneviileys tai ikävystyminen (esim. Kuhn 1976). Modernin kehyksissä melankolia voi muuntua poliittisesti aktiiviseksi, räyhäkkääksi huonotuulisuudeksi, josta Flatley (2008: 6) on Baudelairen yhteydessä kirjoittanut.

\footnotetext{
17 Esim. Astradur Eysteinsson (1990: 187, 205) on pitänyt tietynlaista negatiivisuutta ominaisena modernismille; sitä leimaa häiriön tai keskeytyksen estetiikka, joka haastaa perinteiset käsitykset kerrottavuudesta ja tarinankerronnasta ja näihin käsityksiin sisäänrakennetut oletukset todellisuuden luonteesta.

${ }^{18}$ Vaikean empatian käsitteestä ks. Eric Leake (20l4). Vaikeasta empatiasta modernismissa ja 1900-luvun kirjallisuudessa ks. myös. Lissa et al. 2016; Meretoja 2017.
} 
Kaunokirjallisuuden edistys- ja kehitysoptimismia kiistävä, antimoderni eetos sai ilmaisunsa vastahankaisena kiihkeytenä, äkeytenä ja ärtyisyytenä (Compagnon 2005: 169). ${ }^{19}$ Siihen on liittynyt nykyaikaistumiskehitykseen kohdistuvaa inhoa ja torjuntaa (Rossi 2020: 18) tai vaihtoehtoisesti emotionaalista viileyttä, ikävystymistä ja apatiaa (esim. von Koppenfels 2007). Taiteen modernille ominainen nykyaikakriittisyys ja siihen liittyvät tunteet ovat myös tämän kokoelman tutkimien tekstien kasvualustana. Kuten monet kokoelman artikkeleista osoittavat, nykyaikakriittistä vastahankaisuutta kielentäessään kirjallisuuden modernismit nojaavat usein negaatioiden poetiikkaan, jossa idylliä riisutaan ironian, parodian ja kansallisia ihanteita kyseenalaistavien vastakuvien keinoin. Samalla nykyajan kritiikki kääntyy usein mennyttä kohtaan tunnetuksi nostalgiaksi, jossa kiukkuun kätkeytyy kadotetun paratiisin kaipuuta. Edistyksen kertomuksesta vieraantuneiden hylkiösankareiden katkeruuskin voi olla käänteinen kiintymyksen ilmaisu tai toive rakentaa vaihtoehtoista tunneyhteisöä. Myös kielteiset tunteet voivat olla tehokkaita yhteenkuuluvuuden kokemuksen virittäjiä. Renanin (I882: 27) mukaan yhteinen kärsimys yhdistää jopa enemmän kuin jaettu ilo tai saavutetut voitot, sillä koettelemukset vaativat kaikkien huomiota, kollektiivisia ponnistuksia ja painuvat voimakkaasti kansakunnan kulttuuriseen muistiin. Sodanaikaiseen yhteishengen nostatukseen on toisinaan vedottu myös COVID 19-pandemian aiheuttaman kansallisen poikkeustilan aikana kuluneena vuonna 2020. Rinnastus on historiallisessa kapeakatseisuudessaan syystä herättänyt myös kriittisiä vastaääniä.

\section{Suomalaiset ahdistukset kansakuntaa rakentamassa}

Suomalaisista ahdistuksista ammentavan kansallisen kertomuksen ytimessä on ajatus kansakunnasta tunneyhteisönä, jota kielteiset tunteet sekä rakentavat että hajottavat. ${ }^{20}$ Kollektiivisten tunteiden näkökulmasta kansakunnat voidaan ymmärtää tunneyhteisöiksi, joissa tunteiden emotionaalinen ja sosiaalinen liima sitoo kansalaisia toisiinsa ja liittää toisilleen tuntemattomia ja toisistaan erillisiä yksilöitä yhteen kansakuntaan, tai vaihtoehtoisesti sulkee yksilöitä yhteisön ulkopuolelle. Tästä näkökulmasta kansallisidentiteetissä ei ole kyse vain kielellisistä, etnisistä tai uskonnollisista tekijöistä, vaan ilmiöstä, jota ei voi erottaa tunteista ja erilaisista tunneilmaisun rekistereistä.

\footnotetext{
${ }^{19}$ Compagnon (2005: 9) puhuu epätoivon energiasta ja tunteen kiihkeydestä, joka on eri tavoin leimannut antimodernia ajattelua Chateaubriandista Baudelaireen ja Nietzscheen. ${ }^{20}$ Kysymys tunteiden merkityksestä yhteisöjen toiminnassa ja yksilöiden välisessä vuorovaikutuksessa on viime vuosina herättänyt kiinnostusta eri aloilla kielentutkimuksesta historiaan ja filosofiaan. On tutkittu jaettuja ja kollektiivisia tunteita, tunteiden intersubjektiivisuutta ja historiallisia tunneyhteisöjä sekä tunteiden ilmaisun ehtoja ja ilmaisua sääteleviä sosiaalisia normeja. (Ks. esim. von Scheve ja Salmela 20I4; Rosenwein 2006 ja 2016; Reddy 200I.) Tunteet ei ole vain yksilön sisäisiä subjektiivisia tiloja, "vain tunteita". Kuten esimerkiksi Ahmed (2004) on korostanut, tunteet liikkuvat yhteisössä ja muokkaavat yksilöiden välisiä rajapintoja, ja ohjatessaan yleistä tunneilmastoa niistä voi tulla poliittisesti merkittäviä muutoksen moottoreita.
} 
Tunneyhteisön käsite on alun perin historioitsija Barbara Rosenweinin: Rosenwein (2006: 24-25; 2016: 3) kutsuu tunneyhteisöiksi sosiaalisia ryhmiä, joita tietynlaiset tuntemisen ja tunteiden ilmaisun tavat yhdistävät. Tunneyhteisö voidaan ymmärtää suppeammin rajatuksi arkiseksi yksiköksi, kuten tietty perhe, työyhteisö tai seurakunta. Väljemmin ymmärrettynä tunneyhteisön käsitteellä voidaan viitata esimerkiksi jonkin aikakauden sosiaaliseen luokkaan ja sitä yhdistävään emotionaaliseen tyyliin. Rosenweinin mukaan tunneyhteisöllä ryhmänä on yhteinen affektiivinen panos; yhteisiä kiinnostuksen kohteita, tavoitteita tai arvoja, jotka määrittelevät ryhmälle ominaista emotionaalista tyyliä, tuntemisen tapaa. Jos Rosenweinin käsitteitä sovelletaan kansallisen tunneyhteisön tarkasteluun, niin Suomea kuviteltuna kansakuntana voidaan kuvata tunneyhteisöksi käsitteen laajemmassa merkityksessä. Laajat tunneyhteisöt voivat pitää sisällään erilaisia tunneyhteisöjen variantteja, emotionaalisia alakulttuureja ja emotionaalisia "vastatyylejä" suhteessa vallitsevien yhteisöjen tuntemisen tapoihin (Rosenwein 2016: 3). Kokemuksen suomalaisuudesta voivat jakaa arvoiltaan, uskomuksiltaan ja tavoitteiltaan hyvin erilaiset kansalaiset, vaikka heitä yhdistää kiintymys kuviteltuun kansakuntaan tai väljemmin siihen kuulumisen tunne. Yksilöt ovat tavallisesti yhtäaikaisesti useamman tunneyhteisön jäseniä, ja he ikään kuin navigoivat erilaisten tunneyhteisöjen sekä niihin liittyvien tavoitteiden, arvojen ja normien välillä.

Myönteisessä merkityksessä kansakunta tunneyhteisönä voi toimia positiivisena yhteisöllisenä voimana, joka lisää yksilön kokemusta elämän merkityksellisyydestä ja vahvistaa toimijuuden kokemusta. Nykytutkimuksen valossa tiedon ja tunteiden alueet eivät ole toisensa poissulkevia vaan tunteet ovat kiinteästi yhteydessä yhteisöissä muodostuneisiin uskomuksiin ja arvoihin (esim. Nussbaum 200I: 19, 23). Tunteiden kohtaaminen yhteisössä voi lisätä ymmärrystä tavoista, joilla tunteet vaikuttavat poliittiseen päätöksentekoon sekä kytkeytyvät historiallisiin tapahtumiin ja kulttuurisiin kokemuksiin. Sara Ahmed on kuvannut, kuinka kielteisetkin tunteet, kuten kollektiivinen syyllisyys tai häpeä voivat olla luomassa kulttuurisesti avoimempaa ja moniäänisempää yhteiskuntaa, joka huomioi väkivallan historian ja sosiaalisen epätasaarvon ja pyrkii muuttamaan vallitsevia epäkohtia. Esimerkiksi menneisyyden häpeän ja häpeällisyyksien kohtaaminen voi toimia sovittavana tekona, jonka myötä kansakunnasta voi tulla "ihanteensa veroinen" (Ahmed 20I4: 144). Kollektiiviset tunteet ja ymmärrys tunneyhteisön dynamiikasta voivat auttaa työstämään historian traumoja ja löytämään tasa-arvoisempia poliittisia ratkaisuja. ${ }^{21}$

Kuten historioitsija William Reddy (200I: I22-I28) on korostanut, yksilön kannalta voimaannuttava yhteisö on emotionaalisesti mahdollisimman liberaali ja sallii tunteiden vapaan ilmaisun. Kansakunnat tunneyhteisöinä voivat muovautua myös vapautta ja yksilön tavoitteiden saavuttamista rajoittaviksi. Muun muassa Ahmed (2004 ja 20l0) on

${ }^{21}$ Tästä ovat kirjoittaneet kollektiivisen syyllisyyden yhteydessä Ferguson ja Branscombe (20|4). 
osoittanut, kuinka vihan ja pelon kaltaiset kielteiset tunteet luovat syrjivää kansallista politiikkaa ja rakentavat valikoivaa ja ulossulkevaa tunneyhteisöä, jota oikeutetaan vetoamalla isänmaanrakkauden ja kansallisylpeyden kaltaisiin myönteisiin tunteisiin sekä kulttuurisiin kertomuksiin kansallisesta suuruudesta ja paremmuudesta. Myönteisetkin tunteet voidaan valjastaa ulosulkemisen tekniikoiksi. Esimerkiksi populistisessa kielenkäytössä rasismi voidaan naamioida isänmaanrakkaudeksi: en vihaa toisia vaan rakastan maatani (ks. Ahmed 2004: 160). Positiiviset yhteydentunteet ja yhteisön voimasta liikuttuminen voivat yhtä hyvin rakentaa vihayhteisöjä ja sysätä massoja väkivaltaan. ${ }^{22}$

Kaikkiin yhteisöihin sisältyy paitsi tunteita, myös käsityksiä tunteista, tunteisiin liittyviä oletuksia ja tunteiden ilmaisua sääteleviä normeja. Reddyn (200 I: 129) käsittein yhteisöjen tapaa normittaa tunteita voidaan kuvata tunnehallinnoksi (emotional regime). Hän viittaa käsitteellä erityisesti poliittisiin hallintoihin liittyviin normatiivisiin tunteisiin sekä virallisiin rituaaleihin, käytäntöihin ja puheakteihin, jotka pyrkivät ohjaamaan, säätelemään tai manipuloimaan ja sanktioimaan yhteisön jäsenten tunteita ja tunneilmaisua. Yhteisöjen tunnenormit ovat julkilausuttuja tai epäsuorasti ilmaistuja käsityksiä sosiaalisesti hyväksytyistä tunteista ja tunteiden ilmaisun tavoista. Poliittista tunnehallintoa muovataan ja työstetään erilaisilla sosiaalisilla rituaaleilla, kulttuurisilla symboleilla ja kertomuksilla. Kirjallisuus voi rakentaa ja pönkittää nationalismin poliittisia tavoitteita, mutta toisaalta haastaa ja kritisoida erilaisia poliittisia tunnehallintoja ja niihin liittyviä normatiivisia tunteita.

Useissa kokoelman artikkeleissa keskiössä ovat kriittiset vastakertomukset, jotka kyseenalaistavat konventionaaliseksi miellettyä kansallista kertomusta ja vallitsevia poliittisia näkemyksiä kannattelevia kansallistunteita. Konservatiivisen nationalismin kiistäminen ei kuitenkaan automaattisesti merkitse suuntaa kohti liberaalia tai arvoiltaan demokraattista tunneyhteisöä. Päin vastoin, kuten Marko Tapiota ja Pentti Linkolaa käsittelevät artikkelit tuovat esille, perinteistä kansallista kertomusta haastava vastatarina voi tarjoilla jopa valtakertomusta synkempää maskuliinisuuden ihannetta ja uhoa. Molempien kirjoittajien tuotantoa on hyödynnetty myös tukemaan ja oikeuttamaan poliittisesti (ääri)oikeistolaisia ja demokratian kannalta kyseenalaisia näkemyksiä. Nykyaikakriittisen vastahangan taustalta voi kuultaa myös tunkkaista nostalgiaa, jossa valoisan tulevaisuuden kiistäminen merkitsee menneeseen takertumista. Suomalaiset ahdistukset -kokoelman artikkelien aineiston valossa on esimerkiksi todettava kansallisen kertomuksen sukupuolittunut luonne. Kansallisiksi miellettyihin teemoihin ovat tarttuneet erityisesti mieskirjailijat, jotka usein ovat myös tutkimuksen polttopisteessä. Tämän kokoelman puheenvuoroista moni paneutuu mieskirjailijoiden tuotantoon, jossa ahdistus rakentuu suhteessa kansallisten, konservatiivisten arvojen kiistämiseen tai menneisyyden ihannointiin. Viola Parente-Čapkován artikkeli, joka tarkastelee venäläisyyden esityksiä L. Onervan teoksissa, on tässä mielessä tervetullut poikkeus. Sukupuolen

${ }^{22}$ Kollektiivisten tunteiden manipulatiivisesta potentiaalista, ks. von Scheve ja Salmela 20I4:xv. 
ja kansallisen tunneyhteisön kysymys on selvästikin yksi jatkotutkimusta kaipaavista alueista.

Suomalaiset ahdistukset -julkaisun viisi ensimmäistä artikkelia käsittelevät kotimaista kirjallisuutta 1800-luvun lopun naturalismista modernismiin ja nykykirjallisuuteen analysoiden suomalaisten omakuvaa ja suomalaisuuden suhdetta muihin kansoihin ja kansanluonteisiin. Kaksi viimeistä artikkelia tarkastelevat suomalaista ahdistusta esseistiikan ja blogitekstien valossa. Molemmat tekstilajit hyödyntävät kaunokirjallisten tekstien tapaan ironian ja parodian keinoja herättääkseen lukijoissaan tunteita tai jopa muuttaakseen lukijan asenteita suhteessa suomalaisiin "meihin" ja "muihin".

Kokoelman avaa Riikka Rossin artikkeli "Nälkävuosien tunnehallinto, Z. Topeliuksen 'Septembernatten' (1867) ja K. A. Tavaststjernan Hårda tider (I89I)”, joka tarkastelee Topeliuksen runon ja Tavaststjernan romaanin tunnevaikutuksia. Rossi tulkitsee Topeliuksen runoa ajan kristillis-isänmaallista tunnehallintoa peilaavana ja rakentavana tekstinä, jossa keskiössä on kollektiivinen syyllisyys: luonnonkatastrofi kuvataan Jumalan rangaistuksena kansakunnan maallistumisesta. Rossi tarkastelee Topeliuksen runon eettisiä asetelmia suhteessa nälkävuosien historiaan. Empatia nälän uhreja kohtaan on luonteeltaan vallitsevaa tunnehallintoa vahvistavaa, rakkautta kuvataan vastavuoroisuutta edellyttävänä lahjana ja köyhyys ylevöitetään onnellisuuden ja liikuttuneisuuden tunteilla. Tavaststjernan romaanissa esille nousevat kulttuurisesti rumat tunteet ja moraalisesti ristiriitaiset henkilöhahmot, jotka haastavat lukijaa kohtaamaan velvoittavan rakkauden ja helpon myötätunnon ehdot. Ironinen kerronta kyseenalaistaa nälkävuosien politiikkaa ja ylempien luokkien myötätuntoa sekä ilmaisee moraalista halveksuntaa valtaapitäviä kohtaan. Lisäksi ironian tehtävänä on rakentaa uutta kriittistä tunneyhteisöä.

Viola Parente-Čapkován artikkeli "The Effeminate Race? Ideas and Emotions in L. Onerva's Representations of Russianness" puolestaan tarkastelee venäläisyyden esittämistä L. Onervan novellissa “Manja Pavlovna” (kokoelmasta Murtoviivoja, 1909) sekä romaanissa Yksinäisiä (1917) ja tutkii venäläisyyteen näissä teoksissa kiinnittyviä affekteja ja emootioita. Analysoidessaan L. Onervan teosten tunneesitysten kieltä ja retoriikkaa Parente-Čapková osoittaa, kuinka tekstit kommentoivat ironisesti suomalaisuuden ja venäläisyyden kuvauksia, stereotypioita ja ideoita. Teokset kyseenalaistavat ajan poliittisiin jännitteisiin ja rasistisiin rotuteorioihin kytkeytyviä käsityksiä venäläisestä sielusta primitiivisenä, atavistisena ja dekadenttina Toisena, joka yhtä aikaisesti kiehtoo ja pelottaa. Allegoristen kuvausten jännitteet - erityisesti Venäjään projisoidut pelot - heijastavat Suomen kulttuurista asemaa idän ja lännen välissä. Parente-Čapkován artikkeli nostaa esille myös Onervan teksteissä muukalaisuuden kohtaamiseen ja kokemiseen kytkeytyvän häpeän tunteen, joka on usein muovannut kansakuntia tunneyhteisöinä.

Anna Hollsten analysoi artikkelissaan "'Kuin pätsissä mä seisoisin'. Sankarikuolema ja ristiriitaiset tunteet talvi- ja jatkosotarunoudessa" suomalaista sota-ajan runoutta tunnehallinnon ja runojen tunnevaikutusten näkökulmasta. Hollsten tarkastelee sankarikuoleman motiivin esiintymistä hymnin, elegian ja ruumisrunon lajityypeissä ja pohtii, kuinka 
vuosien 1940-1944 aikana julkaistu runous osallistui sota-ajan nationalistisen tunnehallinnon vahvistamiseen sekä toisaalta haastoi isänmaallisen uhrimielen eetosta. Osa ajan runoudesta oli avoimen kriittistä kuvatessaan sodan aiheuttamaa kärsimystä ja aseveljien kuoleman herättämiä ristiriitaisia tunteita. Isänmaan puolesta uhrautumista ei kuitenkaan missään vaiheessa kyseenalaistettu järjestelmällisesti. Päinvastoin, sankarikuolemaa käsittelevä runous toi läheisensä menettäneille ihmisille myös lohtua kansallisessa poikkeustilanteessa eikä sitä kirjoitettu vain propagandistisiin tarkoituksiin.

Artikkelissaan "Taakankantajat. Marko Tapion Aapo Heiskasen viikatetanssi sodanjälkeisen ahdistuksen ja syyllisyyden kuvauksena" Elise Nykänen tarkastelee kielteisten tunteiden esityksiä ja tunne-efektejä Tapion vuonna 1956 ilmestyneessä metafiktiivisessä romaanissa. Artikkelissaan Nykänen osoittaa, kuinka ironialle tyypillinen rakenteellinen ja temaattinen kaksikasvoisuus kytkeytyy romaanissa sekä kotimaisen kansankuvauksen tradition että eksistentialistis-filosofisen kirjallisuuden tunnekuvaston muunteluun ja parodiointiin. Kuvatessaan rintamalta palaavan sotamiehen mielen järkkymistä romaani kommentoi erityisesti 1940-luvulla ilmestyneitä kotiinpaluukertomuksia sekä sota-ajan tunneyhteisössä vallinnutta isänmaallisen uhrautuvuuden eetosta. Katoavan idyllin kuvauksissa korostuu päähenkilön ahdistus ja vieraantuminen omasta kansallisesta alkuperästään sekä syyllisyys, jota vanhoista arvoista ja ihanteista luopuminen aiheuttaa. Romaani rakentaa lukijalle vaihtoehtoisia yleisöpositioita, jotka perustuvat erilaisten kulttuurishistoriallisten tunneyhteisöjen olemassaoloon ja vastaanoton malleihin. Teoksen tunnevaikutukset liikkuvat eettisestä vieraantumisesta päähenkilön kärsimyksen tunnistamiseen ja esteettiseen etäännyttämiseen sen mukaisesti, millaiseen vastaanottaja-asemaan lukija ironisen kerronnan kutsumana kulloinkin asettuu.

Artikkelissaan "Voi maamme! Kurjalasta Ruoveden rappioon. Kansallismaiseman vastakuvia" Pirjo Lyytikäinen analysoi, kuinka suomalainen kirjallisuus luo ihanteellisen kansallismaiseman ja kansankuvan negaatioita ja tuottaa tunnevaikutuksia muokkaamalla varhaisempia kirjallisia malleja. Lyytikäinen analysoi ihanteellisen kansallismaiseman vastakuvia Juhani Ahon naturalistisista korpiloukoista Marko Tapion modernin, kapitalisoituvan Saarijärven tuhoutuviin maisemiin sekä Matias Riikosen nykydystopiaan, jossa Ruoveden kansallismaisema muuttuu ilmastoapokalypsin näyttämöksi. Kansallismaisemien vastakuvat välittävät kansallista ahdinkoa, ahdistusta ja pessimismiä, jotka kytkeytyvät sortovallan aikaan, modernin Suomi-projektin vastakkainasetteluihin sekä nykypäivän ilmastokriisiin, joka uhkaa globaalisti olemisen mahdollisuuksia. Lyytikäinen osoittaa, että vaikka matka Ahon naturalistisesta lastusta Tapion vimmaiseen modernismiin ja Riikosen postmoderniin ilotteluun on pitkä, kaikissa kolmessa tekstissä käytetään samantyyppisiä negatiivisten tunnevaikutusten luomisen strategioita melankolisen tunnelman luomisesta inho-naturalistiseen maisemakuvaukseen.

Antti Ahmalan artikkeli "Runo-Suomi vai ekologinen roistovaltio? Pentti Linkola, antimodernit tunteet ja suomalaisuus" tarkastelee Pentti Linkolan tuotannossa esiintyvää puhetta suomalaisuudesta, luonnosta ja 
nykyajasta kiinnittäen huomiota erityisesti modernisaatioon kohdistuviin kielteisiin tunteisiin. Ahmala tutkii artikkelissaan sitä, kuinka suomalainen kansanluonne, kulttuuriperinne ja kirjoittajan henkilökohtainen luontosuhde kietoutuvat Linkolan teksteissä yhteen. Linkola esittää monessa esseessään itsensä suomalaisen tunneyhteisön tulkitsijana, joka tiedostaa kirkkaasti ja pystyy siksi sanoittamaan sen, minkä muut vaistomaisesti ja ristiriitaisesti tuntevat: nykyajan mukavuudessa piilevän kurjuuden ja kaipuun entisen kaltaiseen, ekologisesti ja inhimillisesti kestävämpään elämänmuotoon. Ahmala osoittaa, kuinka Linkolan tekstit pyrkivät ravistelemaan lukijansa hereille sekä järkiperäisen argumentaation että monitahoisen tunteiden dynamiikan kautta: puhumalla suomalaisesta ilosta ja ahdistuksesta, hyödyntämällä sanojen esteettisyyttä ja niiden luomaa tunnelmaa muun muassa luonnon kauneuden tai modernin elämän kurjuuden kuvauksissa, sekä provokaation, ironian ja huumorin affektiivisesti latautunein retorisin keinoin.

Kokoelman päättää Tuija Saresman ja Urho Tulosen yhteisartikkeli "Halla-ahon ahdistus ja ironia. Ulossulkeva suomalaisuus ja ahdas nationalismi Scripta-blogissa", joka tarkastelee suomalaisuuden ja kansallistunteen affektiivista performoimista Perussuomalaisten puheenjohtaja Jussi Halla-ahon blogissa. Halla-aho on julkaissut blogiaan Scripta - kirjoituksia uppoavasta lännestä 2000-luvun alusta saakka. Blogi ja sen vieraskirjasta irrotettu Hommaforum on ollut merkittävässä roolissa kansallismielisen ja maahanmuuttovastaisen liikehdinnän noustessa Suomessa. Saresma ja Tulonen lukevat blogia retoris-performatiivisesti eli kiinnittäen huomiota blogitekstien retoriikkaan ja siihen, kuinka tekstit tuottavat affektiivisia reaktioita.Artikkelissa tarkastellaan tekstien tapaa rakentaa populistiselle vastakkainasettelulle ominaisesti "meidän" ja "muiden" kategorioita, kaksoispuhetta strategiana sekä blogikirjoitusten tyyliä, erityisesti ironiaa tyylikeinona. Lisäksi artikkelissa analysoidaan blogissa lanseerattuja oikeistopopulistisia uudissanoja. Yhdistämällä oikeistopopulismin, nationalismin, affektiivisuuden ja retorisen tyylin tutkimisen Saresma ja Tulonen osoittavat Halla-ahon Scripta-blogin hyödyntävän muun muassa ironiaa affektiivisena keinona, jolla tuotetaan kuviteltua suomalaista kansakuntaa. Isänmaanrakkauden kaltaisten positiivisten tunteiden sijaan suomalaisuus rakentuu blogissa ulossulkevan nationalismin, kielteisiksi koettujen asioiden, kuten maahanmuuton vastustamisen ja viholliskuvien luomisen varaan.

Käsillä oleva artikkelikokoelma on syntynyt Suomen Akatemian rahoittaman Kirjallisuus ja tunteet -projektin puitteissa osana laajempaa SA-tutkimuskonsortiohanketta Kirjallinen elämä. Kirjallisuuden ja arkipäivän rajankäyntiä (LILI 20I5-2019). Kokoelmaa on inspiroinut ja rahoittanut myös meneillään oleva, Koneen Säätiön rahoittama hanke Arktinen hysteria: Oudot pohjoiset tunteet (2020-2022). Lisäksi erikoisnumeron julkaisua on rahoittanut Jenny ja Antti Wihurin säätiö. Kiitämme kaikkia rahoittajia saamastamme taloudellisesta tuesta.

Lisäksi kiitämme Joutsen / Svanen-julkaisua koordinoivaa toimittajaa Anna Biströmiä sekä erikoisnumeron taittajaa Jari Käkelää erinomaisesta ja joustavasta yhteistyöstä. 


\section{LÄHTEET}

\section{Kaunokirjallisuus}

Kanteletar elikkä Suomen kansan vanhoja lauluja ja virsiä. Suomalaisen Kirjallisuuden Seuran Toimituksia 3. Koonnut Elias Lönnrot. 16. painos. Ensimmäinen painos I840. Jyväskylä: Gummerus, 1997.

Leino, Eino 1902: “Lapin kesä.” Teoksessa Kangastuksia. Helsinki: Päivälehden kirjapaino.

Topelius, Zacharias 1937/I886: ”Ditt land.” Teoksessa Boken om Vårt Land. Läsebok för de Lägsta Läroverken i Finland. 19. painos. Esbo: Svenska läromedel, http://runeberg.org/tzbokland/00 I I.html

Topelius, Zacharias 2017: Naturens Bok och Boken om Vårt Land. Magnus Nylund (utg.), ZTS XVII, Helsingfors: Svenska litteratursällskapet i Finland, URN:NBN:fi:sls-6599-I508I56379 (viitattu 26.08.2020)

\section{Muut lähteet}

Anderson, Benedict 1991/1983: Imagined Communities: Reflections on the Origin and Spread of Nationalism. London:Verso.

Bloom, Paul 2016: Against Empathy:The Case for Rational Compassion. New York: HarperCollins.

Boddice, Rob 2018: The History of Emotions. Manchester: Manchester University Press, https://doi.org/I0.7765/978I526I53388

Byrne, Bridget 2017: "Americans in the Making: Myths of Nation and Immigration in Naturalization Ceremonies in the United States." In Katrien De Graeve, Riikka Rossi and Katariina Mäkinen (eds.), Citizenships under Construction: Affects, Politics, Practices. COLLeGIUM vol. 23. Helsinki: Helsinki Collegium for Advanced Studies. http://hdl.handle.net/ I0I38/228628 (viitattu 7.10.2020)

Compagnon, Antoine 2005: Les Antimodernes de Joseph de Maistre à Roland Barthes. Paris: Gallimard.

Cova, Florian \& Julien Deonna 20I4: “Being Moved.” Philosophical Studies vol. 169, 447-466, I0.1007/s I I098-013-0192-9

Deonna, Julien A., Raffaele Rodogno \& Fabrice Teroni 20 I I: In Defense of Shame: The Faces of an Emotion. New York: Oxford University Press, https://doi.org/I0.1093/acprof:oso/9780 I99793532.00I.000 I

Deonna, Julien 2018: "The Emotion of Being Moved." In Christine Tappolet, Fabrice Teroni and Anita Konzelmann Ziv (eds.), Shadows of the Soul: Philosophical Perspectives on Negative Emotions. New York and London: Routledge, 60-68.

Eysteinsson, Astradur 1990: The Concept of Modernism. New York: Cornell University Press, https://doi.org//0.759//978I50172/304

Ferguson, Mark A. \& Nyla R. Branscombe 2014: "The Social Psychology of Collective Guilt." In Christian von Scheve and Mikko Salmela (eds.), Collective Emotions. Oxford: Oxford University Press, $25 \mathrm{I}-265$.

Flatley, Jonathan 2008: Affective Mapping: Melancholia and the Politics of Modernism. Cambridge, Mass. \& London, England: Harvard University Press, https://doi.org/I0.4I59/9780674036963 
Goldie, Peter 20 I I: “Grief: A Narrative Account.” Ratio 24 (2): I 19-137, https://doi.org/I0.1 I I I/j. I467-9329.20 I I.00488.x

Grönstrand, Heidi, Ralf Kauranen, Olli Löytty, Kukku Melkas, HannaLeena Nissilä \& Mikko Pollari (toim.) 2016: Kansallisen katveesta. Suomen kirjallisuuden ylirajaisuudesta. Helsinki: SKS.

Hobsbawm, Eric 1994/1992: Nationalismi. Suom. Jari Sedergren, Jussi Träskilä ja Risto Kunnari. Jyväskylä: Gummerus.

Hogan, Patrick Colm 2009: Understanding Nationalism: On Narrative, Cognitive Science, and Identity. Columbus: Ohio State University Press.

Kirstinä, Leena 2007: Kansallisia kertomuksia. Suomalaisuus 1990-luvun proosassa. Suomalaisen Kirjallisuuden Seuran Toimituksia IIIO. Helsinki: SKS.

von Koppenfels, Martin 2007: Immune Erzähler. Flaubert und die Affektpolitik des modernen Romans. München: Wilhelm Fink, https://doi. org/ I 0.30965/9783846743867

Kuhn, Reinhard 1976: The Demon of Noontide: Ennui in Western Literature. Princeton: Princeton University Press, https://doi.org/10.15/5/ $978 \mid 400886340$

van Lissa, Caspar J., Marco Caracciolo, Thom Van Duuren \& Bram Van Leuveren 2016: "Difficult Empathy. The Effect of Narrative Perspective on Readers' Engagement with a First-Person Narrator". In Marisa Bortolussi, Peter Dixon and Roy Sommer (eds.), DIEGESIS 5.I (20I6), https://www.diegesis.uni-wuppertal. de/index.php/diegesis/article/view/2I I (viitattu 8.9.2020)

Leake, Eric 2014: "Humanizing the Inhumane: The Value of Difficult Empathy." In Meghan Marie Hammond and Sue J. Kim (eds.), Rethinking Empathy through Literature. Vol. 31. [Online]. London: Routledge, 175-185.

Lyytikäinen, Pirjo 1999: "Suomalaiset syntysanat. Suomen kirjallisuus suomalaisuutta kirjoittamassa." Teoksessa Tuomas M. S. Lehtonen (toim.), Suomi, outo pohjoinen maa. Näkökulmia Euroopan äären historiaan ja kulttuuriin. Porvoo: PS-kustannus, I38-165.

Lyytikäinen, Pirjo 2004: Vimman villityt pojat. Seitsemän veljeksen laji. Helsinki: Suomalaisen Kirjallisuuden Seura.

Lyytikäinen, Pirjo 2016: "Tunnevaikutuksia eli miten kirjallisuus liikuttaa lukijaa." Teoksessa Anna Hollsten ja Anna Helle (toim.), Tunteita ja tuntemuksia suomalaisessa kirjallisuudessa. Helsinki: SKS, 37-57.

Maijala, Minna 2008: Passion vallassa. Hermostunut aika Minna Canthin teoksissa. Suomalaisen Kirjallisuuden Seuran Toimituksia I I69. Helsinki: SKS.

Makkonen, Anna I992: "Sivullisia ja kokeilijoita. Näkökulmia I950-luvun proosaan.” Teoksessa Anna Makkonen (toim.), Avoin ja suljettu. Kirjoituksia 1950-luvusta suomalaisessa kulttuurissa. Helsinki: SKS, 93-121.

Menninghaus, Winfried, Valentin Wagner, Julian Hanich, Eugen Wassiliwizky, Milena Kuehnast \& Thomas Jacobsen 2015: "Towards a Psychological Construct of Being Moved." PLoS ONE, 
10(6), Article e0I2845 I. 10.137I/journal.pone.012845I, https:// doi.org/I0.137I/journal.pone.0I2845 I

Menninghaus, Winfried, Valentin Wagner, Julian Hanich, Eugen Wassiliwizky, Thomas Jacobsen \& Stefan Koelsch 2017: "The Distancing-Embracing Model of the Enjoyment of Negative Emotions in Art reception." Behavioral and Brain Sciences, 40, E347, https://doi.org/10.1017/s0 | 40525x17000309

Meretoja, Hanna 2017: The Ethics of Storytelling: Narrative Hermeneutics, History, and the Possible. Oxford: Oxford University Press.

Ngai, Sianne 2005: Ugly Feelings. Cambridge: Harvard University Press, https://doi.org/I0.4I59/978067404I 523

Nussbaum, Martha 200 I: Upheavals of Thought: the Intelligence of Emotions. Cambridge: Cambridge University Press.

Nussbaum, Martha 2004: Hiding from Humanity: Disgust, Shame, and the Law. Princeton: Princeton University Press, https://doi. org/I0.15 I5/978|400825943

Nussbaum, Martha 2018: The Monarchy of Fear:A Philosopher Looks at Our Political Crisis. New York: Simon \& Schuster.

Nykänen, Elise 2018: "Hänen vierellään on valmiina pimeyden päivä. Eksistentiaalisten tunteiden kertominen Kerttu-Kaarina Suosalmen novellissa 'Synti'”. Avain I/2018, 66-79, https://doi. org/ 10.30665/av.70008

Ovaska, Anna 2020: Fictions of Madness: Shattering Minds and Worlds in Modernist Finnish Literature. Helsinki: Unigrafia.

Ratcliffe, Matthew 2015: Experiences of Depression: A Study in Phenomenology. Oxford: Oxford University Press.

Reddy, William 200I: The Navigation of Feeling: A Framework for the History of Emotions. Cambridge: Cambridge University Press, https://doi. org/l0.1017/cbo97805 II51200 I

Renan, Ernst 1882: Qu'est-ce qu'une nation? Conférence fait en Sorbonne, le II Mars 1882. Paris: Calmann Lévy, https://archive.org/details/ questcequunenat00renagoog (viitattu 8.9.2020)

Rosenwein, Barbara H. 2006: Emotional Communities in the Early Middle Ages. Ithaca \& London: Cornell University Press.

Rosenwein, Barbara 2016: Generations of Feeling: A History of Emotions, 600-1700. Cambridge: Cambridge University Press, https://doi. org/10.1017/cbo9781316156780

Rossi, Riikka 2007: Le naturalisme finlandais. Une conception entropique du quotidien. Helsinki: SKS.

Rossi, Riikka 2020: Alkukantaisuus ja tunteet. Primitivisimi 1900-luvun alun suomalaisessa kirjallisuudessa. Helsinki: SKS.

Salin, Sari 2002: Hullua hurskaampi. Ironinen kahdentuminen Jorma Korpelan romaaneissa. Helsinki:WSOY.

Salin, Sari 2008: Narri kertojana. Kultaisesta aasista suomalaiseen postmodernismiin. Helsinki: SKS.

von Scheve, Christian \& Mikko Salmela (eds.) 20I4: Collective Emotions: Perspectives from Psychology, Philosophy and Sociology. Oxford: Oxford University Press. 
von Scheve, Christian \& Salmela, Mikko 2014: "Collective Emotions: An Introduction." In Christian von Scheve and Mikko Salmela (eds.) 20 14: Collective Emotions: Perspectives from Psychology, Philosophy and Sociology. Oxford: Oxford University Press, xiii-xxiv.

Solomon, Robert C. \& Lori D. Stone 2002: “On 'Positive' and 'Negative' Emotions." Journal for the Theory of Social Behaviour. Vol. 32, No. 4, 2002, 417-435.

Tappolet, Christine, Fabrice Teroni \& Anita Konzelmann Ziv 20 I8: Shadows of the Soul: Philosophical Perspectives on Negative Emotions. New York \& London: Routledge, https://doi.org/ I0.4324/978I 3 I 5537467

Tepora, Tuomas 20I I: Sinun puolestas elää ja kuolla. Suomen liput, nationalismi ja veriuhri. Helsinki:WSOY.

Teroni, Fabrice 2018: "Emotionally Charged - The Puzzle of Affective Valence." In Christine Tappolet, Fabrice Teroni and Anita Konzelmann (eds.), Shadows of the Soul: Philosophical Perspectives on Negative Emotions. New York \& London: Routledge, 10-19, https://doi.org/ / 0.4324/978 I 3 I 5537467-2

Viikari, Auli 1996: Kansakunnan kirjoittaminen. Kirjallisuudentutkijain seuran vuosikirja 49, 48 - 53.

Wetherell, Margaret 2012: Affect and Emotion:A New Social Science Understanding. London: Sage, https://doi.org// 0.4I35/978| 446250945

\section{Kirjoittajat}

Riikka Rossi, dosentti, yliopistonlehtori, Tampereen yliopisto.

riikka.rossi@tuni.fi

Elise Nykänen, FT, tutkija, Helsingin yliopisto.

elise.nykanen@helsinki.fi 